\title{
THE RELATIONSHIP BETWEEN ANTHROPOMETRIC PARAMETERS AND VULNERABILITY OF CAROTID ATHEROSCLEROTIC PLAQUES IN TYPE 2 DIABETES MELLITUS
}

\author{
Muamer Suljić1 ${ }^{1}$ Snežana Jovanović-Marković2 ${ }^{\text {, Šefćet Hajrović1 }}{ }^{1}$ \\ Aleksandar Jovanović ${ }^{2}$
}

\begin{abstract}
The primary histopathological feature of diabetic vascular complications is the formation of atherosclerotic plaques.

Ultrasound examination provides not only a quantitative analysis of the plaque, but also the qualitative analysis of plaque vulnerability.

Body fat distribution highly correlates with certain pathologies and an evaluation of this distribution is essential in the estimation of health risks. Waist circumference and WHR index (Waist-Hip Ratio) are highly useful methods in both adipose tissue distribution and cardiovascular and metabolic risk assessment in individual patients, as well as populationwide.

The aim of our study was the assessment of incidence, distribution and vulnerability of carotid atherosclerotic plaques in patients with type 2 diabetes versus healthy controls, and their relation to adipose tissue distribution.

The study involved 101 persons - 51 type 2 diabetics and 50 control patients.

Atherosclerotic plaques were present in $100 \%$ of diabetics vs. $28.12 \%$ of control subjects. Vulnerable plaques were found in $47.06 \%$ of type 2 diabetes patients and in $25.6 \%$ of controls. The results of Mann-Whitney's test show a higly significant difference in the incidence of plaques and plaque instability between the two groups.

The mean waist circumference was significantly higher in type 2 diabetic patients compared to controls $(96.53 \pm 11.51 \mathrm{~cm}$ vs. $87.97 \pm 12.15 \mathrm{~cm}, \mathrm{p}<0.01)$.

The mean waist/hip ratio was significantly higher $(p<0.01)$ in patients with type 2 diabetes $(0.93 \pm 0.08)$. The waist circumference and waist/hip ratio significantly correlated with the athe-rosclerotic plaque instability $(p=0.54, p<0.0001)$.
\end{abstract}

Acta Medica Medianae 2017;56(4):31-37. mellitus

Key words: atherosclerotic plaque, carotid arteries, waist/hip ratio, diabetes

${ }^{1}$ International University in Gorazde, Bosnia and Hercegovina

2University of Pristina, Faculty of Medicine, Republic of Serbia

Contact: Muamer Suljić

Street Hercegovacka 4, 36300 Novi Pazar

e-mail: muamer_suljic@yahoo.com

\section{Introduction}

Overview of historical data

In recent decades, type 2 diabetes has been recognized as a global health problem, partially due to its strong increase in prevalence reaching pandemic proportions, and also because of the high prevalence of its vascular complications. Over $60 \%$ of type 2 diabetic patients die due to cardiovascular complications. Diabetic patients with myocardial infarction and stroke have a 2-4 time higher mortality rates compared to non-diabetics. The relationship between high blood sugar and vascular pathology was well known even 1000 years BC. The famous Persian physician Avicenna was the first to describe the patient with gangrene as a vascular complication of diabetes

The primary histopathological feature of diabetic vascular complications is the formation of atherosclerotic plaques; a timely and adequate diagnosis of the plaque formation and their distribution is the basis of an adequate therapeutic approach.

Yoshida (1956), Sotomura (1959) and Franklin (1961) first used the ultrasound methodology to demonstrate blood flow through the vessels and used it for diagnostic purposes. Further technolo- 
gical improvements brought about the development of strict clinical diagnostic criteria related to differentiation of normal from pathological vessel morphology and blood hemodynamics.

Obesity is considered one of the oldest metabolic diseases, judging from the numerous historical findings from ancient Egypt and the Middle Ages to the present. The imbalance between food consumption and daily energy needs, which is the feature of modern life, often leads to obesity.

\section{Chronic complications of diabetes mellitus}

Chronic diabetic complications affect many organ systems and are responsible for a high incidence of comorbid states and a high mortality rate in patients with type 2 diabetes. Diabetic complications include both non-vascular and vascular complications: vascular complications may be microvascular - affecting primarily small arteries and capillaries, and macrovascular - involving primarily larger arteries (1). Microvascular complications are diabetic neuropathy and nephropathy and a range of ocular changes; macrovascular disease manifests in the form of coronary artery disease, cerebrovascular events and peripheral vascular disorders.

The risk of chronic complications increases with the duration of diabetes. They are usually evidenced in the second decade after the onset of hyperglycemia. Since type 2 diabetics may have a long latent and asymptomatic period of hyperglycemia, many of them have complications at the time of diagnosis. The results of relevant clinical studies (UKPDS, Framingham Study) have shown a significantly higher risk for the development of microvascular (37\% - 50\%) and macrovascular diabetic complications, a 2-3 times greater risk for cardiovascular ones, and a 3-6 times higher risk for myocardial infarction in patients with type 2 diabetes (1).

\section{Obesity}

The distribution of body fat may not only affect one's physique, but also highly correlates with certain diseases and pathological conditions; the distribution of adipose tissue may even be a better indicator of health than BMI (Body Mass Index). For the assessment of fat distribution it is useful to measure waist circumference and calculate the WHR index (Waist - Hip-Ratio). According to the WHO (World Health Organi-zation), WHR should be less than 1 for males and less than 0.85 for females; waist circumference in men should be less than $102 \mathrm{~cm}$ and less than $88 \mathrm{~cm}$ for women.

Based on anthropometric parameters, obesity can be defined as android (male, "apple") and the gynoid (female, "pear" obesity). In the gynoid type of obesity, the excess fat accumulates under the skin, in the lower parts of the body, around the pelvis and thighs and generally contains alpha 2 adrenergic receptors through which catecholamines exhibit their lipogenic action. A greater susceptibility to mechanical complications because of locomotion difficulties, peripheral venous circulation insufficiency, and respiratory failure may occur in these patients more frequently. Notably, this type of obesity may be present in both genders. The android type of obesity (central, visceral, abdominal) means that fat accumulates in the shoulder region, chest and abdomen. It contains mainly beta-adrenergic receptors through which catecholamines exhibit their lipolytic effects and directly lead to an increase in endogenous triglyceridemia (1). This intraabdominal fat increases insulin resistance and is associated with a group of risk factors (ie., the components of the metabolic syndrome: glucose intolerance, low levels of HDL cholesterol, high triglyceride levels, hypertension and obesity), which are called the Reaven syndrome $X$ or metabolic syndrome (2).

Ultrasound characteristics of an atherosclerotic plaque

The most common disease of major arteries is atherosclerosis. Ultrasound is the major diagnostic approach in the evaluation of atherosclerotic carotid artery plaques. It provides not only a quantitative analysis of the plaque (e.g. its length width, thickness of individual plaques and extent of vessel luminal stenosis), but also a qualitative analysis of the plaque vulnerability plaque material, surface of the plaque, and presence of an appositional thrombus. On the basis of this analysis, it can be estimated how much a plaque is "threatening" (vulnerable) regarding the occurrence of cerebrovascular disease (3).

Plaques may be homogeneous (with uniform homogeneous structure), but are often heterogeneous (uneven, with heterogeneous ultrasonographic structure).

Based on their clinical significance, plaques may be classified into:

-complicated (vulnerable, unstable) and plaques.

-non-complicated (non-vulnerable, stable)

Unstable plaques are those with exulcerated surface (ulceration may be seen at points where the lipid part of the plaque is detached from the rest of it), surface with cracks, with thrombosis along the wall (hypoechogenic structure of apposition thrombus) or with hemorrhage (anechogenicity) within the plaque; a large (over $2 \mathrm{~cm}$ ), very hypoechoic plaque may be also considered unstable. (3)

These complicated plaques are unstable, and their parts tend to detach, with consequent embolization of distal arteries.

Anatomical characteristics of atherosclerotic plaque

Atherosclerotic intimal lesions may be classified as early, late and complicated. The classification of 1994 by the American Heart Association and its Committee for Vascular Lesions is 
also more and more widely accepted; this pathological-histological classification recognizes six basic types of lesions, designated by Roman numerals. Type I and Type II are early lesions. Type III is the transitional form between early and late lesions. Type IV and Type V are late, and type VI are complicated atherosclerotic intimal lesions.

With this classification, lesions are clearly pathologically, histologicaly, histochemicaly and ultrastructuraly defined and described. The AHA classification is suitable for standard diagnosis, gives insight into the development of the disease, and allows a correlation with clinical manifestations and with modern diagnostic procedures.

Fissures (cracks), ulcerations (defects) and ruptures (tears) of the plates (lesion type VIa) are formed on the surface of already formed atherosclerotic plaques. As there is no protective layer over the atheromatous core, it develops a direct contact with blood. Atheroma may release its content through a defect directly into circulation and becomes the source of atheromatous embolism. The emboli originating from atheromas mainly consist of cholesterol crystals, so this type of embolism is termed cholesterol embolism (4).

\section{Aim}

The aim of our study was to assess the incidence, distribution and vulnerability of carotid atherosclerotic plaques in patients with type 2 diabetes and in controls (healthy individuals), and their relation to adipose tissue distribution assessed by anthropometric parameters - waist circumference and waist/hip ratio.

\section{Methodology}

The study enrolled 101 persons - 51 type 2 diabetics and 50 control patients. Diabetes was established by at least two fasting plasma glucose levels of $\geq 7.0 \mathrm{mmol} / \mathrm{L}$, or at least one OGTT glucose level of $\geq 11.1 \mathrm{mmol} / \mathrm{L}$, and/or positive history/documentation of diabetes and diabetes treatment. Plasma glucose was determined photometrically, using the GOD-PAP methodology, with normal plasma glucose ranging from 3.6 to 6.1 $\mathrm{mmol} / \mathrm{l}$.

The assessment of carotid plaque vulnerability was done using the ultrasound methodology on Toshiba Cori Vision Pro and Medison devices, and was based on plaque echogenicity, its overall appearance, homogenicity, dimensions, and regularity (lumen border and fibrous cap appearence and thickness).

The Body Mass Index (BMI) was calculated as the ratio of body mass and square of height $\left(\mathrm{kg} / \mathrm{m}^{2}\right)$. Waist circumference $(\mathrm{cm})$ was measured at the narrowest part of the trunk at the level of the navel during quiet expirium, and hip circumference $(\mathrm{cm})$ was measured at the widest part, e.g. at the level of the iliac crest.

\section{Results}

The mean age in the group of patients with type 2 diabetes was $62.42 \pm 10.14$ and in the control group $57.63 \pm 12.12$; the average age of patients in the control and study groups were not significantly different $(p>0.05)$. There were 25 male subjects (49\%) and 26 women (51\%) in the group of patients with diabetes, whereas there were 24 male subjects (48\%) and 26 women (52\%) in the control group. There were not any statistically significant differences in gender distribution between the groups.

Diagram 1 shows the distribution of patients according to the presence and type of atherosclerotic plaques in the carotid arteries in the type 2 diabetics and controls. Atherosclerotic plaques were present in $100 \%$ of diabetics vs. $28.12 \%$ in control subjects. Vulnerable plaques were found in $47.06 \%$ of patients in type 2 diabetes patients and $25.6 \%$ of controls. The results of Mann-Whitney's test show a higly significant difference in the incidence of plaque and plaque instability between two groups.

Diagram 1: Distribution of type 2 diabetics and the control group patients according to the type of atherosclerotic plaques

\section{Type 2 diabetes}

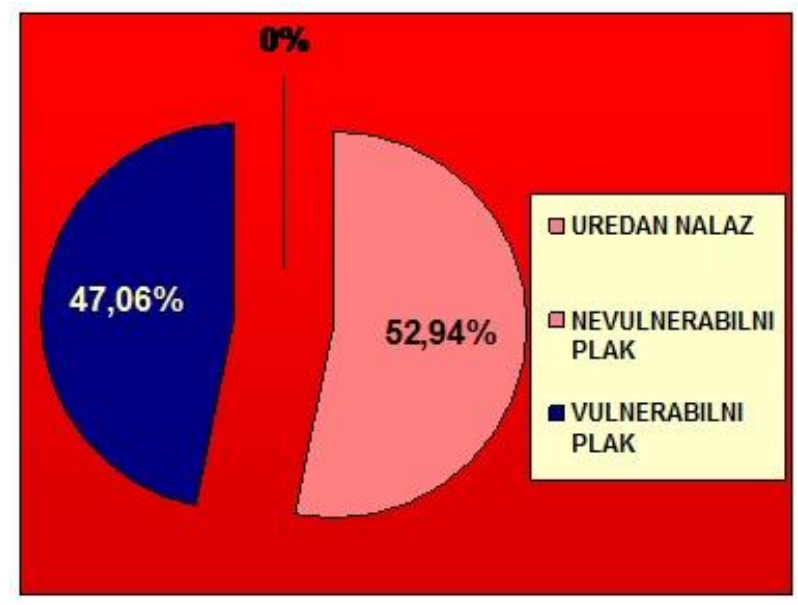

2. Control group

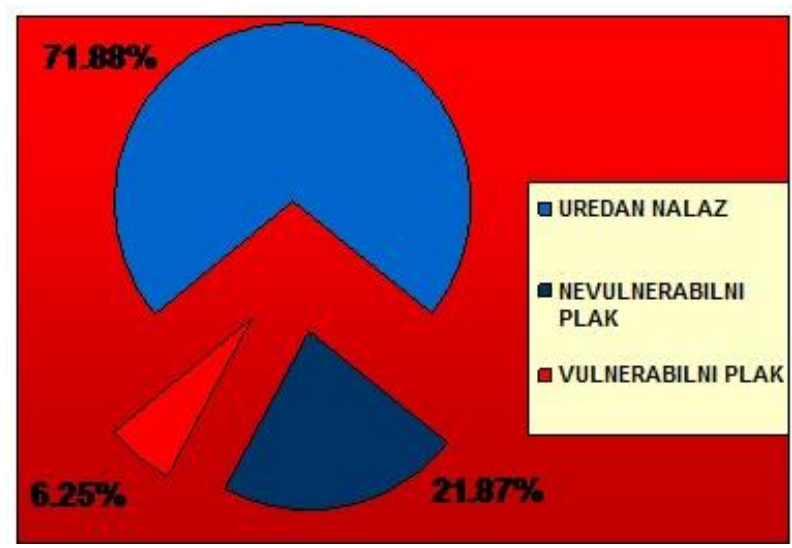


Diagram 2: Mean waist circumferences in patients with type 2 diabetes and patients in control group

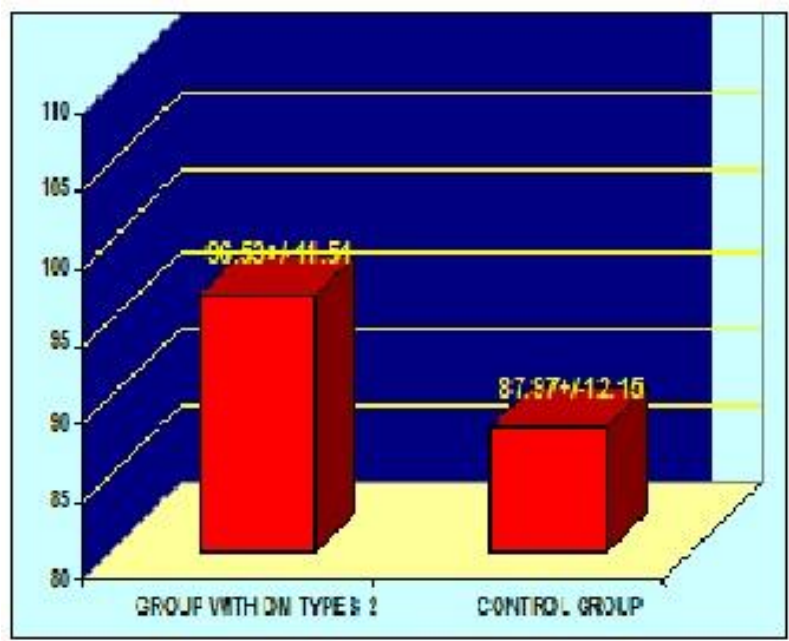

Diagram 3: Mean waist/hip ration in in patients with type 2 diabetes and patients in control group

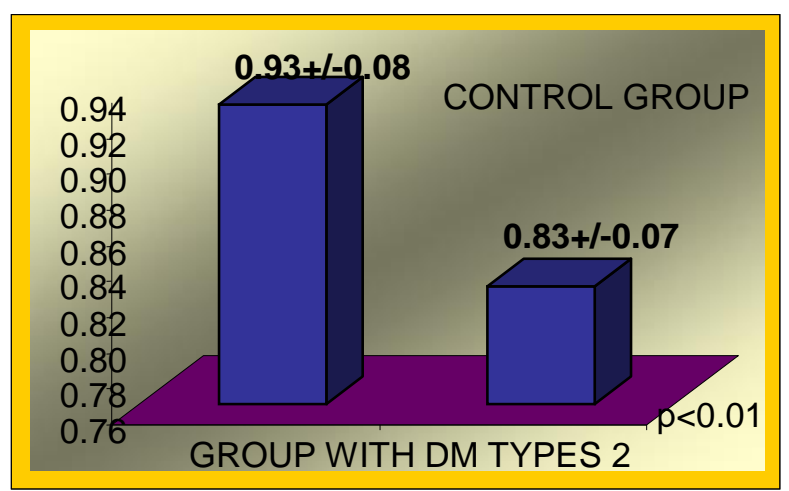

The mean values of relevant anthropometric test parameters and results of the statistical comparison of values between the patients with diabetes and controls are shown in diagrams 2 and 3 .

The mean waist circumference was significantly higher in type 2 diabetic patients compared to controls (96.53 $\pm 11.51 \mathrm{~cm}$ vs. $87.97 \pm 12.15$ $\mathrm{cm}, \mathrm{p}<0.01)$. The mean waist/hip ratio was significantly higher $(p<0.01)$ in patients with type 2 diabetes $(0.93 \pm 0.08)$. Waist circumference and waist/hip ratio significantly correlated with atherosclerotic plaque instability $(p=0.334, p=0.001$ and $p=0.54, p<0.0001$, respectively); plaque vulnerability also significantly correlated with patient body mass indices (Tables 1, 2 and 3).

Table 1: Significant correlations between waist circumference and relevant clinical parameters

\begin{tabular}{|c|c|c||}
\hline & Spearman's $p$ & $\mathrm{p}$ \\
\hline $\begin{array}{c}\text { Diabetes } \\
\text { morbidity }\end{array}$ & 0.354 & $\mathrm{p}=0,001$ \\
\hline Age & -0.321 & $\mathrm{p}=0,006$ \\
\hline Plaque instability & 0.334 & $\mathrm{p}=0.001$ \\
\hline Waist/hip ratio & 0.733 & $\mathrm{p}<0.0001$ \\
\hline $\begin{array}{c}\text { BMI } \\
\text { (body mass } \\
\text { index) }\end{array}$ & 0.742 & $\mathrm{p}<0.0001$ \\
\hline
\end{tabular}

Table 2: Significant correlations between the waist/hip ratio and relevant clinical parameter

\begin{tabular}{||c|c|c||}
\hline & Spearman's & $\mathrm{p}$ \\
\hline Diabetes morbidity & 0.354 & $\mathrm{p}=0.001$ \\
\hline Age & -0.452 & $\mathrm{p}<0.0001$ \\
\hline Plaque instability & 0.54 & $\mathrm{p}<0.0001$ \\
\hline $\begin{array}{c}\text { Waist } \\
\text { circumference }\end{array}$ & 0.733 & $\mathrm{p}<0.0001$ \\
\hline $\begin{array}{c}\text { BMI } \\
\text { (body mass index) }\end{array}$ & 0.402 & $\mathrm{p}<0.0001$ \\
\hline
\end{tabular}

Table 3: Significant correlations between the plaque instability and relevant clinical parameters

\begin{tabular}{||c|c|c||}
\hline & Spearman's $p$ & $\mathrm{p}$ \\
\hline Age & 0.738 & $\mathrm{p}<0.0001$ \\
\hline Diabetes morbidity & 0.709 & $\mathrm{p}<0.0001$ \\
\hline $\begin{array}{c}\text { Waist } \\
\text { circumference }\end{array}$ & 0.334 & $\mathrm{p}=0.001$ \\
\hline Waist/hip ratio & 0.54 & $\mathrm{p}<0.0001$ \\
\hline $\begin{array}{c}\text { BMI } \\
\text { (body mass index) }\end{array}$ & 0.579 & $\mathrm{p}<0.0001$ \\
\hline
\end{tabular}

\section{Discussion}

Nowadays, about 300 million people have diabetes worldwide. Over $90 \%$ of all diabetic patients have diabetes type 2 . The number of patients is growing. Their life expectancy is increased, so the the incidence of late complications of diabetes is on the rise as well.

Atherosclerosis is a complex chronic diffuse inflammatory process, influenced (and initiated) by complex genetic and environmental factors. Blood vessel inflammation of is one of the main factors that lead to atherosclerosis, and diabetes markedly aggravates the degree of inflammation.

The results of several studies have shown that type 2 diabetes significantly increases the risk for CVD (cardiovascular disease). The best known studies (Framingham) which followed 20 - year survival demonstrated that the risk for atherosclerosis was 2 - 3 times higher in diabetics, and with no significant differences for cardiovascular mortality between men and women with diabetes (5).

This high morbidity and mortality from cardiovascular diseases are the not an exclusive consequence of diabetes, but also the result of synergistic actions of other major risk factors (inheritance, obesity, dyslipidemia, hypertension, smoking) (6).

One of the most important risk factors for type 2 diabetes is obesity. During the seventies, having in mind a very strong association between obesity and diabetes, Sims and colleagues created the term "diabesity"; their studies showed that young men without a positive family history of diabetes who were kept on hypercaloric diet for 6 months had a reversible increase in insulin, glucose, triglyceride levels and developed glucose intolerance. Other risk factors for diabetes include family history of diabetes, present abdominal (cen- 
tral) obesity, and mothers with gestational diabetes. Not only the research papers, but also practical experience reveals the fact that most individuals who develop type 2 diabetes are overweight, and the risk for diabetes is further increased if the increased body weight was present in pre-adulthood (7). The relationship between diabetes and heart disease, as well as some other co-morbid states, may be the consequence of a systemic inflammatory condition. Elevated IL-6 and CRP show that obesity alone may lead to the development of hypertension, diabetes, and coronary heart disease, even when none of the other associated diseases were present (8). In general, adipocytes were often considered as a simple fat depots; however, it is now widely accepted that adipose tissue acts as a complex system and must be viewed as a remarkably dynamic endocrine organ. Some factors and hormones which are secreted by adipocytes are leptin, resistin, adiponectin, cytokines, inflammatory mediators, for example TNF alpha, prothrombotic agents, angiotensinogen etc. $(9,10)$.

Earlier authors have shown that obesityrelated comorbidities (diabetes mellitus, hypertension, coronary heart disease, stroke, etc.) are directly correlated with body mass index (BMI) values. However, more recent studies argue that BMI, in itself, may not be an independent factor in the development of comorbidities. This role is now attributed to the visceral adipose tissue. Abdominal (visceral) adiposity is independently associated with insulin resistance and metabolic syndrome (which, as an entity, also includes hypertension, hyperlipidemia and insulin resistance). The factors secreted by the visceral adipose tissue disturb normal lipid metabolism and increase atherogenic potentials. The most important of these factors are free fatty acids, which are predominantly released by visceral adipocytes. Betareceptors are predominant in the visceral compartment in contrast to subcutaneous one. There is also an increase in the activity of lipoprotein lipase associated with glucocorticoid action and lypolysis caused by catecholamines. On the other hand, the factors that decrease the release of free fatty acids, such as insulin, or the abundance of alpha receptors, are predominant in the subcutaneous adipose tissue (11).

Ultrasonographically determined degree of carotid stenosis is one of the most often cited criteria for the classification of patients with high risk of ischemic stroke. Plaque morphology (ie., its stability, vulnerability) is now being increasingly recognised as a risk factor for cerebral ischemia. According to the results of a study by O'Holleran, the persons with less organized plaques (ie., with soft and thick lesions) have a greater risk of transient ischemic attack (TIA) and stroke, even if the stenosis is below $75 \%$, e.g. lower than the degree usually considered to be hemodynamically significant.

Lusby et al. found that $95.5 \%$ of symptomatic patients had new or recent bleeding in the plaque, in contrast to $27 \%$ of asymptomatic patients, who also had an intramural bleeding. Similar results were obtained by Imparato and al. Strepetti showed that the incidence of heterogeneous carotid plaques correlates with the development of new neurological deficiencies. On the basis of these studies, a clear relationship between the plaque structure and incidence of an ipsilateral stroke can be identified (12).

A pathological differentiation between vulnerable and stable plaques is important in predicting the development of acute coronary syndrome. A postmortem examination of the arteries of individuals aged 15-34 years in the PDAY study (Determinats of Atherosclerosis and Youth) who died in an accident, revealed advanced lesions in the right coronary artery and abdominal aorta associated with central obesity. Moreover, when all risk factors were taken into account, it was concluded that the concentrations of total cholesterol, HDL and LDL cholesterol, hypertension and smoking, accounted for only about $15 \%$ of the pathogenetic potential compared to the volume and vulnerability of plaques (13). Prospective studies (Framingham Heart Study, Harvard School of Public Health Nurses Study) demonstrated that obesity is an independent predictor of clinically manifest coronary heart disease (14).

\section{Conclusion}

The prevalence of carotid plaques is significantly higher in patients with diabetes mellitus. The prevalence of unstable (vulnerable) plaques is significantly higher in patients with diabetes compared to healthy controls. The mean waist circumference and waist/hip ratio are significantly higher among the patients with type 2 diabetes compared to controls. The incidence of vulnerable plaques correlates significantly with diabetes type 2 morbidity and the quantity of intraabdominal fat tissue determined by waist circumference and waist/hip ratio values. 


\section{References}

1. Popović S: Klasifikacija dijabetesa - novi kriterijum, u Djordjević P.B.:Diabetes mellitus inovacije znanja X, Medicinski fakultet, Beograd, 2002. str $38-45$

2. World Helath Organiation.Obesity:Preventing and managing the global epidemic(WHO Technical report series N0.894).2000.Geneva.World Helath Organization.

3. Winter R, Ringleb P, Hacke W. Color-coded duplex ultrasound imaging of intimal fibromuscular dysplasia of the carotid artery, Nervenarzt 1998; 69: 905-8. [CrossRef][PubMed]

4. RossR. Atheroslerosis and inflammatory disaese. $\mathrm{N}$ engl J Med 1999; 340:115-26. [CrossRef] [PubMed]

5. Kuller LH. Implications for diabetes prevention and its complications. 59th Annual Scientific Sessions of ADA, San Diego, CA, 1999.

6. Stern MP.Diabetes aned cardiovascular disease. The "common soil"hypothesis. Diabetes 1995; 44: 36974. [CrossRef][PubMed]

7. Steppan CM, Bailey ST, Bhat S, Brown EJ, Banrejee RR, Wright CM, Patel HR, Ahima R, Lazar MA. The hormone resistin links obesity to diabetes. Nature(Lond.) 2001； 409:307-12. [CrossRef] [PubMed]

8. Puhl RM Henderson KE, Borwnell KD. Social consequences of obesity. In: Kpelan PG, Caterson ID, Detz WH, eds. Clinical obesity, $2^{\text {nd }}$ ed. Oxford:Blackwel Publishing, 2005. str. 29-45.

9. Lyznicki JM,Young DC,Rigss JA, et al.Obesity: Assesment and Menangmentin Primary care.
American family Physician. 2001; 63:2185-94. [PubMed]

10. National Institutes of Health, National Heart,Lung and Blood Institute. Clinical guidelines on the identification, evaluation, and treatment of overweight andobesity in adults-the evidence report. Obes Res 1998; 6: 515-2095.

11. Vohl MC, Sladek R, Robitaille J, Gurd S, Marceau P, Richard D, Hudson TJ, Tchernof A. A survey of genes differentiallyezpressed in subcutaneous and visceral adiposetissue in men. Obes res 2004; 12 : 1217-22. [CrossRef][PubMed]

12. Tegeler HC. Carotid and vertebral duplex scanning in secondary stroke prevention and stenting, in: Alexandrov VA. Cerebrovascular Ultrasound in Stroke Prevention and Treatment, 1st ed, by Grotta J, Blackwell Publishing, 2003, 161-170.

13. Schmidt MI, Dunacn BB, Sharrett AR, Lindberg G, Savage $P$ Jet al.for the ARIC Investigators:Marcers of infalammationand prediction of diabetes mellitus in adults (Ahteroscleorosis Risk in Communites Study): a cohort study. Lancet 1999; 353:1649-52. [CrossRef][PubMed]

14. Malik S, Wong ND, Franklin SS, Kamath TV, L'Italien GJ, Pio JR, Williams GR. Impact of the metabolic syndrome on mortality from coronary heart disease, cardiovascular disease, and all causes in United States adults. Circulation. 2004; 110(10):1245-50. [CrossRef][PubMed] 


\title{
ODNOS IZMEĐU ANTROPOMETRIJSKIH MERA I NESTABILNOSTI PLAKOVA NA KAROTIDNIM ARTERIJAMA KOD BOLESNIKA SA TIP 2 DIJABETES MELITUSOM
}

\author{
Muamer Suljić1, Snežana Jovanović-Marković2 , Šefćet Hajrović1, \\ Aleksandar Jovanović ${ }^{2}$
}

\author{
${ }^{1}$ Internacionalni univerzitet u Goraždu, Bosna i Herecgovina \\ Univerzitet u Prištini, Medicinski fakultet Priština, Republika Srbija \\ Kontakt: Muamer Suljić \\ UI. Hercegovačka 4, 36300 Novi Pazar \\ e-mail : muamer_suljic@yahoo.com
}

Osnovni patohistoloski supstrat vaskularnih komplikacija kod bolesnika sa dijabetesom melitusom je aterosklerotski plak.

Ultrazvučna dijagnostika omogućava i kvantitativnu i kvalitativnu analizu plaka.

Različita distribucija masnog tkiva u organizmu je u visokoj korelaciji sa određenim bolestima. Za takve procene veoma je korisno izračunati antropometrijske mere: WHR indeks (Waist-Hip Ratio), tj. odnos struk/kuk i obim struka.

Cilj našeg istrazivanja bio je da se odredi učestalost i nestabilnosti plaka na karotidnim arterijama, kao i razlika u distribuciji masnog tkiva između bolesnika sa dijabetesom melitusom tip 2 i zdravih ispitanika, i da se ispita zavisnost vulnerabilnosti plaka od distribucije masnog tkiva.

$\mathrm{U}$ ispitivanju je učestvovala ukupno 101 osoba u dve grupe. U prvoj grupi bila je 51 osoba obolela od dijabetesa melitusa tip 2, u kontrolnoj 50 zdravih ispitanika.

Plak je nađen kod $100 \%$ bolesnika, nasuprot $28,12 \%$ u kontrolnoj grupi. Vulnerabilni plak nađen je kod 47,06\% bolesnika u grupi sa dijabetesom tip 2 i 6,25\% bolesnika u kontrolnoj.

Analiza Mann-Whitney testom pokazuje da je razlika u učestalosti pojave i nestabilnosti plaka statistički signifikantna. Srednja vrednost obima struka bila je statistički značajno veća kod bolesnika sa dijabetesom tip 2 u odnosu na kontrolnu grupu $(96,53 \pm 11,51 \mathrm{~cm}$ u odnosu na $87,97 \pm 12,15 \mathrm{~cm}, \mathrm{p}<0,01)$. Odnos struk/kuk, bio je statistički značajno viši $(p<0,01)$ kod bolesnika sa dijabetesom tip $2(0,93 \pm 0,08)$ nego kod zdravih. Obim struka $(p=0,334, p=0,001)$, kao i odnos struk/kuk $(\rho=0,54$, $\mathrm{p}<0,0001)$, značajno su korelirali sa nestabilnošću plaka.

Acta Medica Medianae 2017;56(4):31-37.

Ključne reči: plak, karotidne arterije, struk/kuk, dijabetes melitus 